\title{
Fertility and Women Life Expectancy \\ in Krasnoyarsk Territory: \\ Social and Economic Transition \\ and Intraregional Demographic Response
}

\author{
Marina E. Rubleva**, Vladimir F. Mazharov ${ }^{\mathrm{b}, \mathrm{c}}$, \\ Vladimir L. Gavrikov ${ }^{\mathrm{a}}$ and Rem G. Khlebopros ${ }^{\text {a,d }}$ \\ a Siberian Federal University \\ 79 Svobodny, Krasnoyarsk, 660041, Russia \\ ${ }^{b}$ Research Institute for Complex Problems \\ of Hygiene and Occupational Diseases \\ Novokuznetsk-Krasnoyarsk \\ ${ }^{c}$ Krasnoyarsk State Medical University \\ named after Prof. V.F. Voino-Yasenetsky \\ 1 Partizan Zheleznyak Str., Krasnoyarsk, 660022, Russia \\ ${ }^{d}$ International Scientific Research Center \\ for Extreme Conditions of Organism \\ Krasnoyarsk Scientific Center SB RAS \\ 50 Akademgorodok, Krasnoyarsk, 660036, Russia
}

Received 06.07.2016, received in revised form 28.08.2016, accepted 07.10.2016

Demographic processes are often studied one-dimensionally, i.e. the processes are described through dynamics of one demographic parameter. Meanwhile, relationships between different demographic parameters are of general interest. Tolstikhina et al. (Tolstikhina, Gavrikov, Khlebopros, Okhonin, 2013) showed that fertility and life expectancy are negatively correlated among countries of the world. The same relationship of fertility and life expectancy has been studied by us in this research at an intraregional level through the example of Krasnoyarsk Territory. The demographic data from 1995 to 2013 have been used to describe dynamics of the relationship. The main method used was weighted fitting of the data by a linear function, with weights being the population of the territory administrative regions. No statistically significant relationship between the fertility and female life expectancy has been found in 1995, i.e. the regression line on the graph was practically horizontal. However, a negative correlation has been registered in 2000 and, as the fertility grew between 2000 and 2013, the correlation appeared to be stronger and stronger. These findings are discussed on the background of the social and economic transition that Russia experienced since 1990s. Dramatic turmoil of those times may have broken a 'normal' course of demographic processes so that relationships between demographic parameters responded to it by the absence of correlation. Through an adaptation of the population to the new reality coupled with an average improvement

(C) Siberian Federal University. All rights reserved

* Corresponding author E-mail address: marishka6500@mail.ru 
of social and economic situation the correlation between the demographic parameters restored and took the shape that is characteristic of the world countries dataset.

Keywords: Krasnoyarsk territory, demography, life expectancy, general fertility rate, fertility, municipal units, social and economic transition.

DOI: 10.17516/1997-1370-2016-9-11-2742-2755.

Research area: economics.

The demographic picture of any society (population) is determined by a number of fundamental processes and indicators. They include: the population structure, birthrate, fertility, death rate and life expectancy. The problem of methodology and dynamics assessment of the last one are brought to the light in popular works by M.S. Bednii (Bednii, 1984; 1979; 1976), E. Rosset (Rosset, 1981) and others. A detailed description of the demographic shift which happened in Russia in the $20^{\text {th }}$ century is introduced in A.G. Vishnevskii's works (Vishnevskii, 2004; 2006). He addressed the question how the phenomenon of possession of many children has weakened, the birth rate has decreased and institutions of family and marriage have changed in Russia since 1990s till the present time. These works also contain a comparative analysis of the dynamics of total fertility in Russia and other countries in the beginning of the $21^{\text {st }}$ century.

Through the material of demographic processes of the second half of the $20^{\text {th }}$ century in Russia, comparative researches on life, death expectancy have been carried out by (Shkolnikov, Mille, Vallen, 1995) and also on expected aging - by (Safarova, 2005: 23). Within the recent decade M.A. Klupt (Klupt, 2005, 2010) has also addressed the idea of contemporaneity diversity and further development for the theory of demographic transition.

A general interest is paid to those researches, which include the analysis of relationship between different demographic indicators, and also between demographic, on the one hand, and, for example, socio-economic processes, on the other. Back in 1980s a number of authors considered relations between the tendency in declining fertility and indicators of economic development in different countries (Barro, 1991; Caldwell, 1982; Goodman, Koupil, Lawson, 2012). K.I. Morozova et al. (Morozova, Gafarov, Kabanov, 2009) concluded that the level o welfare and fertility are inversely correlated. They also considered the problem of a probable increase in life expectancy due to unbalance in natural resources distribution. Tolstikhina et al. (Tolstikhina, Gavrikov, Khlebopros, Okhonin, 2013) carried out a research where demographic and economic indicators reflected in the UNO database were compared to each other to classify countries regarding their position relatively to the average trend. The authors stated a negative linear correlation between the life expectancy and fertility in the world's countries as a whole.

The researches made at domestic and regional levels play an important role, since the outlined problems can to some extent be solved with political and administrative mechanisms. The Siberian federal District was studied by S.V. Soboleva (Soboleva, 2009). The author described the demographic situation and its estimates in Siberia in the new millennium. In particular, she reveals the mechanism of demographic policy implementation and suggests an option for the strategy of demographic development in Siberia till 2025. In another work she (Soboleva, Chudaeva, 2014) states that since 2006 de-population in Siberia as well as in 
Russia in general has been changed by improved demographic indicators and gives a reason for this phenomenon; she also analyses separately the dynamics of life expectancy of the population both in the Siberian Federal District (SFD) and Russia and the dynamics of total fertility over the period 1980 - 2012. A set of demographic problems in Siberia is considered in the works by (Grigoriev, Soboleva, 2013, Soboleva, Smirnova, Chudaeva, 2011), where the authors point out low social and health conditions in the SFD (what partially explains the low level of birthrate and high infant mortality rate), increasing demographic pressures on the working age population. The authors' scientific focus is also on migration exchange with the countries of Middle and South-West Asia and, in general, on the risks of demographic capacity-building in Siberia. The problems of human capacity development in Siberia are addressed in a prominent work by Ya.A. Leschenko (Leshchenko, 2013), who through the multidisciplinary approach considered a complex of geopolitical, socio-ecological, health and demographic, civilizational and human aspects of its formation and re-production.

The demographic processes in the Krasnoyarsk Territory within the period of socio-economic transformations were analyzed in numerous studies made by regional scientists both at the level of subjects and separate municipal entity and urban districts (Kalinin, Babenko, Mazharov, Vasilieva, 2010; Grigoriev, Mazharov, 2009; Dementiev, Mazharov, 2015; Mazharov, Grigoriev, Plotnikov, Gornii, 2011; Mazharov, Grigoriev, Plotnikov, Baran, 2014; Krupkina, Babenyshev, Gornii, Mazharov, Plotnikov, Tikhonova, 2012; Krupkina, Mazharov, Gornii, 2010; Mazharov, Grigoriev, 2010; Mazharov, Plotnikov, Gornyii, Tikhonova, Krupkina, 2014; Krupkina, Babenyshev, Mazharov, Plotnikov, Gornii, Tikhonova, 2014; Gornii, Mazharov, Krupkina, Babenyshev, 2007; Mazharov,
Plotnikov, Gornii, Babenyshev, Krupkina, Tikhonova, 2012; Gornii, Mazharov, Krupkina, Babenyshev, Plotnikov, 2007).

As it is known, since the beginning of the 1990s the Russian Federation has undergone a drastic re-construction of the socio-political structure which has touched almost all the aspects of citizens' life. This re-construction could not but address a demographic ground of the society which unavoidably had to respond to new developments. From the perspective of description and analysis of these changes a particular interest is the information about how can not only average demographic indicators, but also their links parameters change. As it has been mentioned before, at the international level there is a negative correlation between life expectancy and fertility (Tolstikhina, Gavrikov, Khlebopros, Okhonin, 2013).

\section{Conceptual basis for the research (theoretical framework)}

The demography, as a study of population, is closely linked to other sciences such as sociology, economy, political studies, social philosophy, anthropology, law and, recently, - to ecology. Demographic processes are considerably influenced by socio-economic, or sometimes, rival changes in the society. The purpose of this work is to observe how demographic indicators responded to the socio-economic transformations in the modern history of Russia through the example of the Krasnoyarsk Territory. The indicators for this phenomenon are not the changes in birthrate or mortality per se, but the nature of the links between them (as it is expected, there is a sustainable reliance between the fertility and life expectancy). In this study, thus, we intend to: 1) identify presence or absence of such correlation between the fertility and life expectancy of women in the Krasnoyarsk Territory at the intra-regional level; and 2) find out whether the parameters of 
such correlation have been changed since the middle 1990s till 2010s.

\section{Statement of the problem}

As the problem for the current research we have chosen the relationship between fertility and life expectancy considered globally in the work by Tolstikhina et al. (Tolstikhina, Gavrikov, Khlebopros, Okhonin, 2013). It has been noted that a negative correlation between the life expectancy and fertility has a linear nature. Thus, in this research we are keen on finding out whether this correlation remains or disappears in the period of socio-economic transformations on the Krasnoyarsk Territory.

\section{Materials and methods}

A factual basis for the research was comprised of the data on the number of births and deaths as well as on the life expectancy of women in municipal entities of the Krasnoyarsk Territory. The database of births and deaths has been received from open-accessed resources of Territorial Department of Federal Statistic Service in the Krasnoyarsk Territory (Krasnoyarskstat) ${ }^{1}$. The life expectancy indicators for women were provided by the Laboratory of Health and Social Problems, RI for Complex Hygiene Problems and Occupational Diseases, Siberian Branch of the Russian Academy of Medical Sciences.

The study concerns the period from 1995 to 2013 within which a set of selected years - 1995, 2000, 2005, 2010, 2011, 2012 and 2013 - has been analyzed in details.

The research includes the data on all the municipal entities of the Krasnoyarsk Territory which have been statistically registered in indicators: 43 municipal entities and 7 urban districts of the Territory (including Krasnoyarsk and Norilsk). The current data have been processed through the methods of mathematical statistics carried out by Statistica 10 software package. The main method is based on the calculation of parameters for regression between the life expectancy and fertility which is reflected in standard fertility rates: Crude Birth Rate (CBR) (the number of live births per 1000 inhabitants) and General Fertility Rate (GFR) - a live birth rates (the number of live births per 1000 women of fertile age).

Since all the municipal entities and urban districts are different in their number of residents, some of them influence the regional average indicators more than the others. Similarly, to calculate the regression it is necessary to consider the fact that measurements (points in variables space) related to different municipal entities and urban districts are not equal. As a rule, the accounting of inequality in measurements has been performed though the weightment.

When drawing the line of regression through the set of equal points we find its optimal position so as a loss function is minimized: for example, there can be a minimum sum of squared distances between the points and regression line. If these points are unequal, i.e. some of them "weigh" more than the others, the weighting selects the parameters for regression in such a way that "heavier" points affect the line's position stronger. Most often the line of regression tends to be closer to the "heavier" points. As a weightscale, characterizing the inequality of points in regression parameters calculation, we have used the number of population in municipal entities and urban districts within the corresponding year.

\section{Results and discussion}

The Figure 1 shows the distribution of municipal entities and urban districts of the Krasnoyarsk Territory in the plane of "women life expectancy" - "general fertility rate" in 1995. Following the methods, we have calculated the parameters of linear regressions excluding or including the weighting. In this way, the life 
expectancy is considered to be an independent variable, and the live birth rate - as a dependent one. It can be seen that a non-weighted line of regression has a modest inclination and goes, according to the procedure, approximately through the center of point clouds denoting municipal entities and urban districts. At the same time, the weighted line of regression lies significantly closer to "heavy points" representing major cities (Krasnoyarsk, Norilsk and Sosnovoborsk).

The main feature of such weighted line is its almost horizontal position. From the statistical perspective such position of the regression line indicates that the given variables do not depend on each other. With a view to the physical meaning of these variables, one can note, that in 1996, in the regional municipal entities there was a significant variation of the average life expectancy of women, though they averagely were little different on the general fertility rates.

It might be useful to compare independence of the considered variables with the general socio-economic situation in Russia in the middle of 1990s. As we know, since 1991 the society and economy of this country has undergone profound and largely painful transformations. The official ideology has changed dramatically, leading to a severe psychological disorientation of all the social strata and the living standards have sharply declined. In this context, one may assume that many social stereotypes of fertility behavior have been destroyed. As it has been mentioned before, the global trend is that the population groups (within a country) with high life expectancy rates have lower fertility rates (Tolstikhina, Gavrikov, Khlebopros, Okhonin,

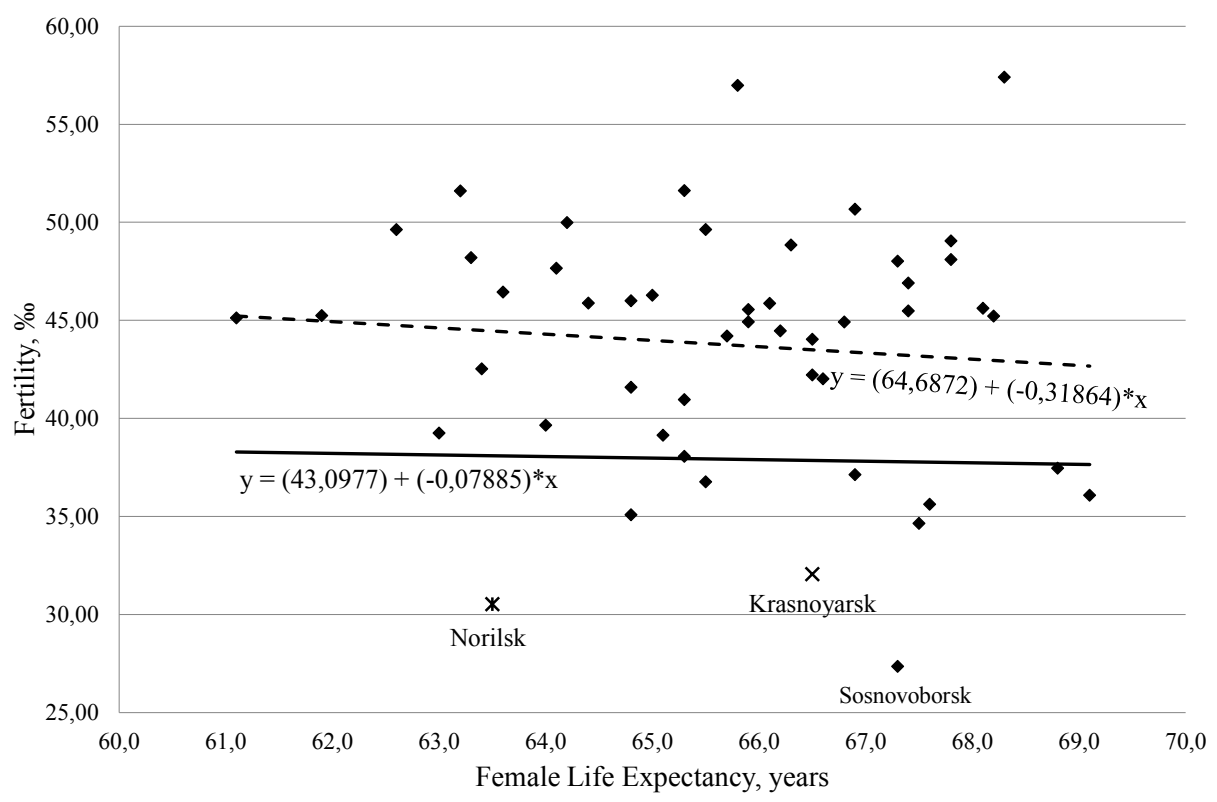

Keys: points denote all the territories, major cities (Krasnoyarsk and Norilsk) are marked by separate symbols; the line of linear non-weighted regression is denoted by hatching, the weighted one - by the full line; regression equations are shown near the corresponding lines.

Fig. 1. Distribution of municipal entities and urban districts of the Krasnoyarsk Territory on the level of special fertility rates and women life expectancy in 1995 
2013). In other words, globally between the life expectance and fertility one may observe a negative correlation.

As it can be thought, disappearance of such correlation in any region indicates about certain processes taking place in the society.

The Figure 2 shows the dynamics of distribution of municipal entities and urban districts in the plane "women life expectancy" "general fertility rates" over the period 1995 2000. To provide a vivid demonstration among all the data we have randomly selected a number of municipal entities: 1) major cities; 2) significantly changed entities; 3) almost not-changed entities. The symbols related to one and the same municipal entity are linked by arrows.

The averaged-weighted general fertility rate for the total data has declined over the period 1995 - 2000 due to the fact that many of the municipal entities have shown the related decline in this indicator. Still, it is obvious, that there is a difference between the municipal entities with a predominance of rural and urban population ${ }^{2}$. Many of entities located far from the regional center have shown a strong negative dynamics: they have met a sharp decrease both in the life expectance indicator and general fertility rates. The major cities have also encountered a decline of the last indicator, though these urban districts (excluding Sosnovoborsk) have grown in the life expectancy figures.

The life expectancy considered on a certain territory can be influenced by different processes. Most strongly it is affected by mortality rates and features of migrations flows (Bednii, 1979: 52). It is likely that over the given period in the cities of this region there have been changes influenced on the mortality rates.

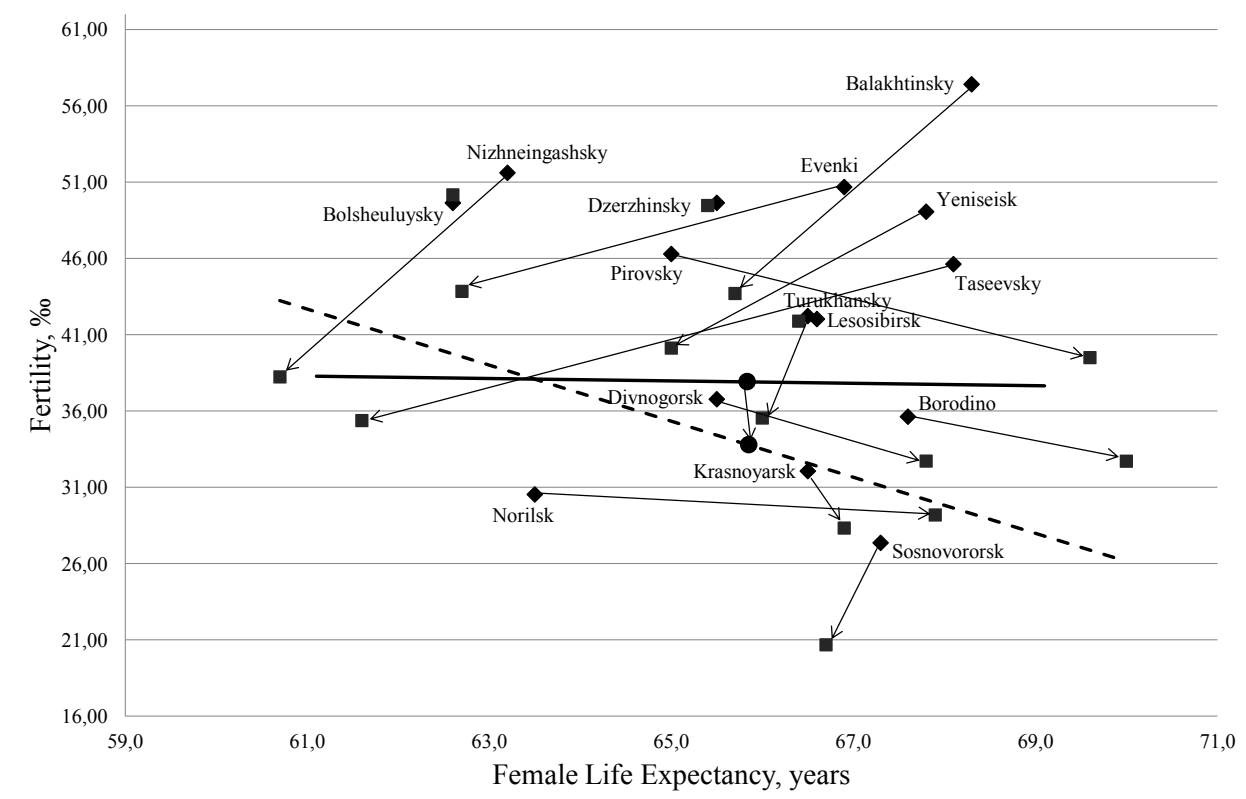

Keys: the single straight line denotes the weighted regression line in 1995; hatching - in 2000; " symbolizes the position of municipal entities in 1995; "Ш" symbolizes their position in 2000; "•" - changes in average-weighted life expectancy and general fertility rates regionally in general from 1995 to 2000.

Fig. 2. Dynamics of distribution of municipal entities and urban districts in the plane of "women life expectancy" - "general fertility rates" over the period 1995 - 2000 
Such probable changes could include improvement of health facilities, and decline in the share of strata which are more likely exposed to mortality (against the backdrop of total population).

A significant contribution to the life expectancy dynamics is made by migration (Bednii, 1979: 52), since the migration flows are not a random selection from the population of the territory from which people mainly migrate. There can be a situation, when one territory brings a "mortality export" to the other territory, in the case if the migration is made mainly by those categories of the population characterized by high indicators.

In this regard, a separate comment should be made concerning Norilsk. As it is known, since 1995 there has been implemented a program "From North to South" persons from the Polar regions to south districts of the Territory (Shushenskii, Minusinskii districts). Such selection processes for older people could possibly influence on a considerable increase of the life expectancy in this northern city.

From the statistical point of view, as the result of disposition of many municipal entities in the plane of "women life expectancy" - "general fertility rates" to 2000 , the nature of relationship between indicators also changed. As it can be seen from the Figure 2 (dashed line) and the Table, the regression line has obtained a statistically changed entities, i.e. in comparison with 1995 in 2000 there were relationship between the given demographic indicators.

To some extent one can conclude that against the backdrop of average decline in demographic indicators during the period 1995 - 2000 the set of municipal districts has shown reconstruction of relationship between the life expectancy and fertility that corresponds with the global tendency (Tolstikhina, Gavrikov, Khlebopros, Okhonin, 2013). On closer examination of the position of different municipal entities on the plane of indicators (Fig. 2) it becomes obvious that the relationship between them represents a reflection of differences between rural and urban realia and life styles. It also can be evident from the results of our calculations which proved a clear direct relationship between the share of rural women in the analyzed territories and the general fertility rates in $2013\left(\mathrm{r}_{\mathrm{x} / \mathrm{y}}=+0,673\right)$, and inverse relationship - between the given share and total fertility rate $\left(r_{x / y}=-0,597\right)$.

The Figure 3 contains a graphic representation of how the intraregional relationship between the general and crude birth rates changed over the period 1995 2013. As it has been mentioned before, in 1995 the correlation between them was statistically absent. From 1995 to 2000 there was a migration of municipal entities with the considered plane that caused both a decrease of the average weighted indicators (Fig. 2), and a statistically important correlation between them. Within the period 2000 - 2013 this correlation underwent considerable quantitative transformation. In this period of time showed not only a high recovery in average weighted women life expectancy and general fertility rates, but also a significant increase in inclination of the correlation line. Such closeness of these relationships, as a rule, enhanced in that period of time though suffered certain fluctuations (Table).

As there are substantial grounds for believing that the correlation line's inclination reflects differences between the rural and urban lifestyles, then, consequently, a contrast between them should had increased in the period from 2000 to 2013. Obviously, the differences between life styles lay in the plane of economic standards as well as in psychological attitudes of the society.

In Table, where $\mathrm{X}, \mathrm{Y}$ are dependent and independent variables, respectively, slope a indicates the value of inclination for the regression 


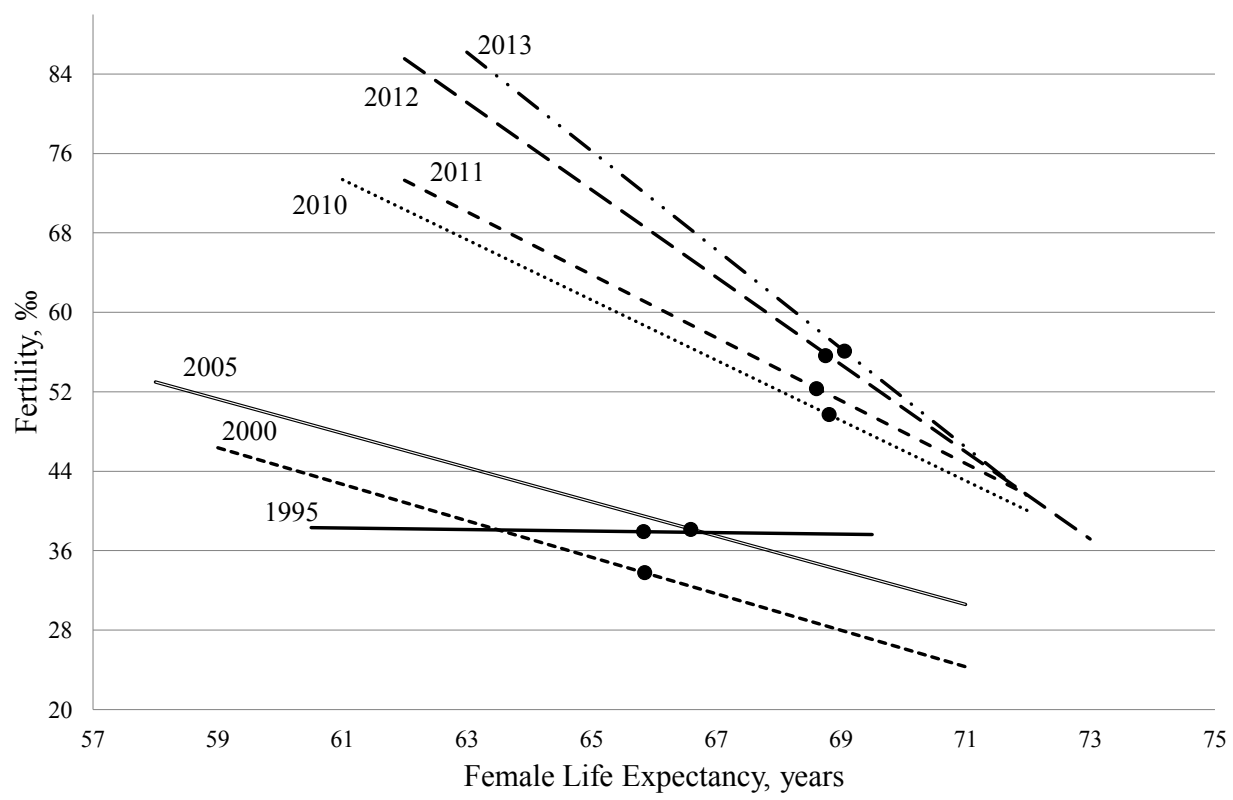

Keys: straight lines symbolize the line of weighted regressions over different years written near the corresponding line; "• means the levels of average weighted indicators over the whole region within relevant years.

Fig. 3. Changes in relationships between the special fertility rate and women life expectancy over the period 1995 -2013 in the Krasnoyarsk Territory

Table. Values and standard errors of parameters evaluation for the linear regression $\mathrm{Y}=\mathrm{a} * \mathrm{X}+\mathrm{b}$ and Pearson correlation coefficient $\left(\mathrm{r}_{\mathrm{x} / \mathrm{y}}\right)$ in the set municipal entities and urban districts

\begin{tabular}{|c|c|c|c|c|c|c|}
\hline \multirow{2}{*}{ Year } & \multicolumn{2}{|c|}{ Slope (a) } & \multicolumn{2}{c|}{ Constant (b) } & \multirow{2}{*}{$\mathrm{R}^{2}$} & $\mathrm{r}_{\mathrm{x} / \mathrm{y}}$ \\
\cline { 2 - 5 } & $\mathrm{a}$ & $\mathrm{SE}$ & $\mathrm{b}$ & $\mathrm{SE}$ & 0,000269 & $-0,094$ \\
\hline 1995 & $-0,07885^{*}$ & 0,17377 & 43,09769 & 11,44379 & 0,250 \\
\hline 2000 & $-1,8365$ & 0,098472 & 154,7018 & 6,487336 & 0,308684 & $-0,250$ \\
\hline 2005 & $-1,7220$ & 0,047544 & 152,8528 & 3,160188 & 0,616209 & $-0,554$ \\
\hline 2010 & $-3,0313$ & 0,113709 & 258,2754 & 7,826548 & 0,491245 & $-0,388$ \\
\hline 2011 & $-3,1709$ & 0,110384 & 269,9007 & 7,574944 & 0,538918 & $-0,343$ \\
\hline 2012 & $-4,3962$ & 0,120195 & 358,0939 & 8,273767 & 0,66332 & $-0,522$ \\
\hline 2013 & $-4,9693$ & 0,129194 & 399,2626 & 8,925024 & 0,680071 & $-0,631$ \\
\hline
\end{tabular}

line, $\mathbf{b}$ is constant, SE - standard error; $\mathrm{R}^{2}$ strength of relationship; $\mathrm{r}_{\mathrm{x} / \mathrm{y}}-$ Pearson correlation coefficient; ${ }^{*}$ Insignificant at $\mathrm{p}<0,05$; all the other parameters are significant at $\mathrm{p}<0,05$.

As it is known, in 2006 a sub-program called "Maternity Capital" aimed at encouraging families for second and subsequent children birth was adopted. According to the statistics reflected in the Figure 3, this very period was characterized by a marked improvement in the average weighted indicators and increase in inclination of the relationship line. On the one hand, one can state that in terms of relative growth rates of the general fertility there were no differences between typical urban and far-fromcenter districts. Thus, the general fertility rate in 2000 in Krasnoyarsk was 28,3 \%o, in 2013 $48,5 \%$. For the municipal district with relatively 
low indicators (Taseevskii) these values were 35,4 and $57,0 \%$ correspondingly. In the district with relatively high indicators of the general fertility rate (Karatuzskii) these values were 45,3 and $81,8 \%$ in 2000 and 2013 correspondingly. Thus, the coefficient growth for the city within the given period of time was 1,71 , and for the districts - from 1,61 to 1,8 , and, consequently, the general fertility rate increased on average proportionately for different municipal entities and urban districts of the Krasnoyarsk Territory.

On the other hand, indeed, this proportion signals about a growing absolute gap between the urban and rural types of municipal entity that is reflected in the increasingslope of the regression line. No matter, whether the general fertility rate's growth was caused by the sub-program implementation or by any other factors, it appears that within the framework of general fertility rate municipal districts mainly characterized by the rural lifestyle react significantly more actively. It means that the growth of general fertility rate occurs proportionately to the observed one in the beginning of the given period, though one might expect that in districts with initially high rate indicator its growth would be slower. At the same time, one might expect that in the districts with initially low indicator values this growth would be stronger (i.e. low base effect).

The differences between rural and urban populations seen at the intraregional level in the context of demographic indicators are manifested at the international level (Tolstikhina, Gavrikov, Khlebopros, Okhonin, 2013). It can easily be noted, though, that the rural and urban lifestyles are likely to denote quite complex social phenomena which include, for example, physical living conditions or the maintained stereotypes of reproductive behavior and, not in the least, differences in economic well-being. These factors should (Bednii, 1979: 35) be often considered as an object to review within the attempts to explain the relationship between on average relatively low fertility rate among wealth strata and, vice versa, between higher indicators of fertility rates among poorest strata.

Thus, D. W. Lawson, R. Mace (Lawson, Mace, 2008) use the models of "resource dilution" to analyze the dependence of the growth of children body considered as a biomarker for the health condition on whether a child has siblings. A longitudinal study made by these researchers was aimed at testing the hypothesis related to a possible competition between brothers and sisters for the resources represented by their parents. The authors have shown that those children who have siblings are statistically lower (in height) than single children and besides can be characterized by slower growth. The authors conclude that even within the context of relatively "satisfied" western societies children are not defended from damages to their health which is likely to come from reductions of parents' investments. As it is reported, the later children are more intensively influenced by the necessity to share their intrafamily resources with others.

A.Goodman et al. (Goodman, Koupil, Lawson, 2012) consider a conflict between behavior strategies which takes place in the modern societies. Its nature is that the behavior oriented on reaching a high socio-economic success contradicts the behavior which provides a reproductive success. By considering a unique cohort of 14000 people born in Sweden between 1915 and 1929, the authors noted that a low fertility rate together with the initial socioeconomic status determine a high status for the next four generations. The most vivid effect is seen when an initial socio-economic position is high. At the same time, the low fertility rate and initially high position do no mean a long-term reproductive success. The results received by the authors, thus, support the idea that in the modern societies declines in fertility rates represent a 
strategic reaction to the local necessity to bring up a socially and economically successful person, but these results contradict the adaptive models anticipating the long-term sustainability within low fertility rates.

V.Berg et al. (Berg, Rotkirch, Väisänen, Jokela, 2013) examined the question of what personal characteristics are related to intended and unintended pregnancies. The authors handled the data on 8336 men and women born in 1958 in the UK, applying the famous "Big Five" psychomodel used for the personal characteristics analysis. The research resulted in the fact that the personal characteristics are linked with intended and unintended pregnancies quite differently. As it turned out, the intended pregnancies are connected with such female features as a tendency to agreements and low openness to a new experience. Among male characteristics the authors identified a high extraversion, high emotional stability, high integrity and low openness to a new experience.

The mentioned above researches as well as those which are similar to them provide us with quite important information which allows suggesting hypothesis and mechanisms that are likely to explain the link between demographic indicators. In particular, the analyzed correlation between the general fertility rate and women life expectance can appear naturally if there are sustainable differences distinguishing the rural and urban lifestyles. For example, if the rural lifestyle is marked by a high focus on the longterm (biological) adaptation, by large mental conservatism and below-the-average health care standards which determine high risks for women's lives, then the urban lifestyle can be oriented more on the local socio-economic success, on the need in a diverse sensory experience (entertainment) and on better perinatal medicine conditions.

Form this point of view, the relationship between the general fertility rate and women life expectancy represents some kind of "norm" for the period of demographic shift. Alongside with this, the researches mentioned above (Goodman, Koupil, Lawson, 2012; Lawson, Mace, 2008; Berg, Rotkirch, Väisänen, Jokela, 2013), as a rule, do not contain a dynamic analysis of interaction between the demographic and any other factors. In this work we have shown that in terms of profound socio-economic and ideological transformations of the society a "normal" relationship between demographic indicators can be destroyed at least at the intraregional level. Those effects we have identified can be called an intraregional demographic respond of the population to the social changes. As it has appeared, this relationship can be re-constructed within the process of adaptation to new circumstances. Reconstruction in this sense means a partial correspondence with the tendencies seen globally in the correlation - life expectancy correlation (Tolstikhina, Gavrikov, Khlebopros, Okhonin, 2013). Unfortunately, the data on general fertility rate and women life expectancy in the municipal entities and urban districts of the Krasnoyarsk Territory before 1990 is unavailable that makes it difficult to investigate the relationship over a longer period of time.

\section{Conclusion}

Thus we have observed the relationship between women life expectancy and general fertility rates in the Krasnoyarsk Territory over the period $1995-2013$. To carry out this research we have mainly calculated the parameters of regression between the life expectancy and fertility. The latter has been expressed through the standard coefficients of fertility (crude birth and general fertility rates) with Statistica 10 software program and weightment procedure. The analysis is statistically based on the births and deaths database over the given period of time and on the data on life expectancy in municipal 
entities and urban districts of the Krasnoyarsk Territory.

The received results reflect the relationship between general fertility rate and women life expectancy in 1995 and changes in it over the period $1995-2000$ and 1995 - 2013. It is known that in the 1990s Russia underwent the socio-economic shocks accompanied by breaks in the fertility life expectancy correlation (the regression line is horizontal), but since 2000 the character of this relationship has started changing: there has been a decline in the average weighted general fertility and life expectancy rates, although the regression line during the time has gained the statistically significant slope increasing since 2000. Such effect demonstrates the fact that during the period of socio-economic transformations the Krasnoyarsk Territory underwent all the stages of demographic movement: from depopulation in 1990s and the beginning of 2000s to re-construction of the reproductive values. These processes were accompanied by the birth growth and mortality decline. Nevertheless, the analyzed region was similar to the global tendencies (Tolstikhina, Gavrikov, Khlebopros,
Okhonin, 2013) and characterized by the fact that its municipal entities and urban districts with high indicators of the life expectancy have lower fertility rates.

There has also been identified that the considered relationship between municipal entities and urban districts reflects the differences between the rural and urban lifestyles. On average, the general fertility rate increased proportionately on all the territories as a possible result of the implementation of Prior National Project "Health" and, in particular, of its sub-program "Maternity Capital" aimed at giving a birth for second and subsequent children. The work also contains the idea that in the terms of profound socio-economic transformations a significant dependence between demographic indicators can be broken and re-constructed within the process of living conditions normalization at the intraregional level.

The identified effect requires further investigation both at the regional and national levels, since the obtained results may well contribute to the demographic policy development in the country and its regions.

\footnotetext{
http://krasstat.gks.ru/wps/wcm/connect/rosstat_ts/krasstat/ru/

2 The scientific literature accepts such terms as "conventionally rural" and "conventionally urban" styles of life. These terms do not necessarily coincide with a common comprehension of rural and urban settlements.

http://rossovet.ru/item/550663-programma-sever-yug-.html
}

\section{References}

Bednii M.S. (1979). Medical and demographic study of human population, In Statistika [Statistics], 224.

Bednii M.S. (1984). Demographic transition of health, In Finansy i statistika [Finances and Statistics], 246.

Bednii M.S. (1976). Life expectancy in cities and villages, In Statistika [Statistics], 96.

Blinova T.V., Vialshina A.A. (2012). Reproduction habits of village women and value of children in family, In Vestnik SGSEU [Journal of Saratov Socio-Economic Institute], 4(43), 165-170.

Dementiev V.V., Mazharov V.F. (2015). Forecast of demographic processes in Krasnoyarsk Territory for 2015-2019, In Sbornik. nauch. tr. Krasnoyarsk: KrasGMU [Collection of scientific works: Krasnoyarsk State Medical University named after Prof. V.F. Voino-Yasenetski], 1, 24-29.

Gornii B.E., Mazharov V.F., Krupkina I.V., Babenyshev S.V., Plotnikov N.Ju., (2007). Territorial features of dynamics and structure of demographic losses in Krasnoyarsk territory, In Trudy VI 
Vseross. konf. po finansovo-aktuarnoi matematike i smezhnim voprosam. Chast' vtoraia [Proceedings of the VI National Conference on Finance and Actuarial Mathematics and Interdisciplinary Problems. Part 2]. Krasnoyarsk: IVM SO RAN, 40-44.

Gornii B.E., Mazharov, V.F., Krupkina, I.V., Babenyshev S.V. (2007). Features of dynamics and structure of demographic losses in Krasnoyarsk territory, In Materialy 9-go Vserossiiskogo nauchnoobrazovatelnogo foruma «KARDIOLOGIIA 200» [Proceedng of the IX National Scientific and Research Forum “Cardiology 200”.] Moscow, 60-62.

Grigoriev Ju.A., Mazharov V.F. (2009). Natural regeneration of population in Siberian Federal Okrug at the beginning of finance and economic crisis, In Vestnik Kuzbasskogo nauchnogo tsentra [Journal of Kuzbass Research Center], 9, Kemerovo, 68-70.

Grigoriev Ju.A., Soboleva S.V. (2013). Modern condition of reproductive health as factor of fertility decrease in Siberia, In Region: ekonomika i sotsiologiia [The Region: economics and sociology], 2(78), 215-236.

Kalinin K.Ie., Babenko A.I., Mazharov V.F., Vasilieva Ju.Ju. (2010) In Analysis of dynamics of demographic processes in the Krasnoyarsk Territory, In Mat. XLV nauch.-prakt. konf. s mezhdunar. uchastiem [Proceedings of the XLV Scientific and Research Conference with International Participation], Novokuznetsk, 95-98.

Klupt M.A. (2005). Theory of demographic development: institutional perspective, In Obschestvennie nauki i sovremennost [Social Sciences and Modernity], 2, 139-149.

Klupt M.A. (2010). Demographic agenda for $21^{\text {st }}$ century: theories and realities, In Sotsiologicheskie issledovaniia [Social Studies], 8, 60-71.

Krupkina I.V., Babenyshev S.V., Mazharov V.F., Plotnikov N.Ju., Gornii, B.E., Tikhonova T.V. (2014). Methodology to estimate the impact of social and economic condition of a territory on social health, In Mat. XLIX nauch.-prakt. konf. s mezhdunar. uchastiem [Proceeding of the XLIX Scientific and Research Conference with International Participation]. Kemerovo: Primula, 66-71.

Krupkina T.V., Babenyshev, S.V., Gornii B.E., Mazharov V.F., Plotnikov N.Ju., Tikhonova I.V. (2012). Measurement of social and economic factors in a demographic model, In Mat. XLVII nauch.prakt. konf. s mezhdunar. uchastiem [Proceeding of the XLVII Scientific and Research Conference with International Participation]. Kemerovo: Primula, 103-107.

Krupkina T.V., Mazharov V.F., Gornii B.E. (2010). Social and economic factors and loss of vital potential, In Trudy 9 Mezhdunarodnoi konferentsii FAMJeT [Proceeding of the IX International Conference FAMJeT], 173-177.

Leshchenko Ia.A. (2013). Development of human potential of Siberia: problems of social regeneration of regional community. Irkutsk: Izd-vo Ottisk, 514.

Mazharov V.F., Grigoriev Ju.A. (2010). Birth rate of population of Krasnoyarsk territory in the $1^{\text {st }}$ decade of 21st: several variant of estimations, In Mat. XLV nauchno-prakt. konf. s mezhdunar. uchastiem [Proceedings of the XLV Scientific and Research Conference with International Participation]. Novokuzneck, 139-143.

Mazharov V.F., Grigoriev Ju.A., Plotnikov N.Ju., Gornii B.E. (2011). Birth rate dynamics in Krasnoyarsk territory for 1993-2009, In Mat. Vseross. nauch.-prakt. Konf [Proceedings of the National Scientific and Research Conference]. Moscow: Ekon. inform, 1, 92-95.

Mazharov V.F., Plotnikov N.Ju., Gornii B.E., Tikhonova I.V., Krupkina T.V. (2014). Medical and demographic processes in social and economic zones of Krasnoyarsk territory in 2000-2012, In 
Voprosy saniepidblagopoluchiia naseleniia SFO: mat.nauch.-prakt. konf [Problems of Sanitary Welfare Heritage in the Siberian Federal District: proceedings of the scientific and research conference]. Krasnoyarsk, 155-160.

Mazharov V.F., Plotnikov N.Ju., Gornii, B.E., Babenyshev S.V., Krupkina I.V., Tikhonova T.V. (2012). Birth rate in Krasnoyarsk territory in first decade of $21^{\text {st }}$ century, In Mat. XLVII nauch.-prakt. konf. s mezhdunar. uchastiem [Proceeding of the XLVII Scientific and Research Conference with International Participation]. Kemerovo: Primula, 118-121.

Mazharov, V.F., Grigoriev, Ju.A., Plotnikov N.Ju., Baran O.I. (2014). Dynamics of population structure in social and economic zones of Krasnoyarsk territory, In Sotsialnie aspekti zdoroviia naseleniia [Social aspects of the population's health] (Web resource), 39(5), 6.

Morozova K.I., Gafarov V.V., Kabanov Ju.L. (2009). Demographical factors of society development, theoretical and methodological aspect, In Mir nauki, kulturi, obrazovaniia (ekologiia, kulturologiia, filologia, iskusstvovedenie, pedagogika, psikhologiia) [The World of Sciencre, Culture and Education (ecology, cultural studies, philology, art studies, pedagogics and psychology)], 4 (16), 275-281.

Rosse Je. (1981). Human life expectancy, In Progress, 384.

Sadykov R.M. (2014). Demographic crisis as threat to social security of administrative units, In Sotsiosfera [Social Sphere], 4, 140-144.

Safarova G.L. (2005). Demographic aspects of population ageing in Russia, In Otechestvennie zapiski [National Remarks], 3, 23.

Shkolnikov V.M., Mille F., Vallen Zh. (1995). Life expectancy and mortality in Russia in 19701993: analysis and prognose. Moscow Centr Karnegi.

Soboleva S.V. (2009). Priorities and most important directions of demographic policy in Siberia, In Region: ekonomika i sotsiologiia [The Region: economics and sociology], 2, 83-95.

Soboleva S.V., Chudaeva O.V. (2014). Demographic situation in Siberia and Russia: tendencies and perspectives. Sib. gos. geodezich. akad. Novosibirsk: SGGA, 1, 11-21.

Soboleva S.V., Smirnova N.E., Chudaeva O.V. (2011). Risks in development of demographic potential of Siberia, In Region: ekonomika i sotsiologiia [The Region: economics and sociology], 4, 98-115.

Tolstikhina O.S., Gavrikov V.L., Khlebopros R.G., Okhonin V.A. (2013). Demographic Transition as Reflected by Fertility and Life Expectancy: Typology of Countries, In Journal of Siberian Federal University, Humanities \& Social Sciences, 6, 890-896

Vishnevskii A. G. (2004). Five challenges of the new age, In Mir Rossii [The World of Russia], 13(2), 3-23.

Vishnevskii A.G. (2006). Demographic modernization of Russia 1900-2000, In Novoe izdatelstvo [New Edition], 601.

Barro R.J. (1991). Economic growth in a cross section of countries, In The Quarterly Journal of Economics, CVI, 425, 407-443.

Berg V., Rotkirch A., Väisänen H., Jokela M. (2013). Personality is differentially associated with planned and non-planned pregnancies, In Journal of Research in Personality, 47(4), 296-305.

Caldwell J.C. (1982). The wealth flows theory of fertility decline. London: Academic Press.

Goodman A., Koupil I., Lawson D. W. (2012). Low fertility increases descendant socioeconomic position but reduces long-term fitness in a modern post-industrial society, In Proceedings of the Royal Society of London B: Biological Sciences, 279(1746), 4342-4351. 
Lawson D.W., Mace R. (2008). Sibling configuration and childhood growth in contemporary British families, In International Journal of Epidemiology, 37(6), 1408-1421.

\title{
Фертильность и ожидаемая продолжительность
}

жизни женщин в Красноярском крае:

внутрирегиональный

демографический отклик

на фоне социально-экономических

трансформаций

\author{
М.Е. Рублева ${ }^{a}$, В.Ф. Мажаров ${ }^{б, в}$, \\ В.Л. Гавриков ${ }^{\text {, }, ~ Р . Г . ~ Х л е б о п р о с, ~}{ }^{\text {, г }}$ \\ ${ }^{a}$ Сибирский федеральный университет \\ Россия, 660041, Красноярск, пр. Свободный, 79 \\ ${ }^{\sigma}$ НИИ комплексных проблем гигиень \\ и профессиональных заболеваний \\ Новокузнецк-Красноярск

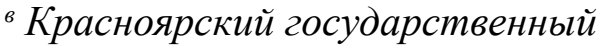 \\ медицинский университет \\ им. проф. В.Ф. Войно-Ясенечкого \\ Россия, 660022, Красноярск, \\ ул. Партизана Железняка, 1 \\ ` Международный научный иентр исследований \\ экстремальных состояний человека при Президиуме \\ Красноярского научного иентра СО РАН \\ Россия, 660036, Красноярск, Академгородок, 50
}

Рассматривается демографическая ситуаџия в Красноярском крае в период с 1995 по 2013 г. В статье используются методы вычисления параметров линейной регрессии между ожидаемой продолжительностью жизни и фертильностью женщин, проведена процедура «взвешивания» демографических показателей. Обнаружено, что Красноярский край и в период сочиально-экономических трансформачий 1990-х и 2000-х годов следует общемировой тенденции, характеризующейся обратной зависимостью между ожидаемой продолжительностью жизни и фертильностью женшин. Выявлено, что значимая зависимость между исследованными демографическими показателями может нарушаться и восстанавливаться в процессе адаптации к новым условиям жизни как в городских, так и в сельских муниципальных образованиях.

Ключевые слова: Красноярский край, демография, ожидаемая продолюительность жизни, специальный коэффициент рождаемости, фертильность, муниципальные образования, сочиально-экономическая трансформация.

Научная спещиальность: 08.00.00 - экономические науки. 